\title{
DESKRIPSI PEMAHAMAN KONSEP DALAM MENYELESAIKAN SOAL-SOAL INTEGRAL
}

\author{
Ernawati $^{1}$ \\ Program Studi Pendidikan Matematika ${ }^{1}$, Fakultas Keguruan dan Ilmu \\ Pendidikan $^{1}$, Universitas Muhammadiyah Makassar ${ }^{1}$ \\ ernawati@unismuh.ac.id ${ }^{1}$
}

\begin{abstract}
Abstrak
Penelitian ini bertujuan untuk menganalisis pemahaman konsep dalam menyelesaikan soal-soal integral. Penelitian ini dilakukan di Kelas XII IPA SMA Tridharma MKGR Makassar pada tahun ajaran 2019/2020 semester ganjil. Subjek dalam penelitian ini sebanyak 5 siswa yang dipilih dari siswa unggulan di kelas tersebut. Jenis penelitian ini adalah penelitian kualitatif. Instrumen penelitian yang digunakan adalah tes integral dan pedoman wawancara. Penelitian ini menganalisis pemahaman konsep dalam menyelesaikan soal-soal integral dengan 5 indikator yaitu, menyatakan ulang konsep (MUK), mengklasifikasi objek sesuai konsep (MOK), memberikan contoh dan bukan contoh sesuai konsep (MCK), menyajikan konsep dalam bentuk representasi (MKR), dan mengklasifikasikan konsep atau alogritma pemecahan masalah (MAK). Hasil dari penelitian ini menunjukan bahwa dari 5 subjek, hanya 2 siswa yang termasuk kategori tingkat pemahaman tinggi dan selebihnya terdapat kategori sedang dan rendah. Indikator pemahaman konsep yang paling dipahami siswa yaitu, menyatakan ulang konsep (MUK), mengklasifikasi objek sesuai konsep (MOK), memberikan contoh dan bukan contoh sesuai konsep (MCK), menyajikan konsep dalam bentuk representasi (MKR), dan mengklasifikasikan konsep atau alogritma pemecahan masalah (MAK) yang paling sulit dipahami oleh siswa.
\end{abstract}

Kata Kunci: Pemahaman konsep, integral

\section{A. Pendahuluan}

Peranan pendidikan sebagai usaha sadar untuk meningkatkan sumber daya manusia yang menjadi perhatian khusus bagi pemerintah dan masyarakat, sehingga pemerintah selalu mengadakan pembaharuan untuk mengembangkan dan meningkatkan pendidikan nasional. Pendidikan adalah hal yang sangat diprioritaskan, karena pendidikan merupakan kewajiban yang berlangsung sepanjang hayat. Salah satu bidang studi yang mempunyai peranan penting dalam dunia pendidikan dan dalam menghadapi masalah kehidupan sehari-hari adalah matematika. Menurut Permendiknas No. 22 Tahun 2006 (dalam Syarif, 2016:93) mata pelajaran Matematika perlu diberikan kepada semua peserta didik mulai dari sekolah dasar untuk membekali peserta didik dengan kemampuan berpikir logis, sistematis, kritis dan kreatif, serta kemampuan bekerjasama. Menurut Depdiknas 
(dalam Setiari, dkk, 2012:03) matematika diartikan sebagai ilmu tentang bilangan, hubungan antar bilangan, dan prosedur operasional yang digunakan dalam penyelesaian masalah mengenai bilangan. Ide-ide matematika yang bersifat abstrak dituangkan dalam bentuk simbol dimana simbol-simbol dalam matematika pada umumnya masih "kosong dari arti" sehingga dapat diberikan arti kepada simbolsimbol itu sendiri sesuai dengan lingkup semestanya. Keberadaan simbol ini memberi peluang yang besar pada matematika untuk digunakan dalam berbagai ilmu dan kehidupan nyata Soedjadi (dalam Maarif, 2015:225).

Secara umum, tujuan pembelajaran matematika pada jenjang sekolah menengah atas (SMA) menurut kurikulum tingkat satuan pendidikan (KTSP) 2006 adalah memberikan penekanan pada penataan nalar, pembentukan sikap siswa, dan memberikan keterampilan pemecahan masalah dalam penerapan matematika, baik dalam kehidupan sehari-hari maupun dalam membantu mempelajari ilmu pengetahuan lainnya. Faktor penentu tercapainya tujuan pembelajaran matematika sangat dipengaruhi oleh guru dan siswa. Guru hendaknya dapat memilih dan menggunakan strategi, metode maupun teknik yang banyak melibatkan siswa aktif dalam belajar. Tercapainya tujuan pembelajaran matematika dapat dilihat dari hasil prestasi belajar matematika siswa. Untuk dapat mencapai prestasi yang baik, siswa dituntut untuk menyelesaikan berbagai jenis soal, baik berupa soal uraian maupun soal dalam bentuk pilihan ganda. Dilihat dari sudut pengklasifikasian bidang ilmu pengetahuan, pelajaran matematika termasuk ke dalam kelompok ilmu-ilmu eksakta, yang lebih banyak memerlukan pemahaman daripada hapalan. Untuk dapat memahami suatu pokok bahasan dalam matematika, siswa harus mampu menguasai konsep-konsep matematika dan keterkaitannya serta mampu menerapkan konsepkonsep tersebut untuk memecahkan masalah yang dihadapinya. Berkenaan dengan itu (Ruseffendi, 1991) menyatakan bahwa Terdapat banyak siswa-siswa yang setelah belajar matematika, bagian yang sederhanapun banyak yang tidak dipahaminya, banyak konsep yang dipahami secara keliru”. Matematika dianggap sebagai ilmu yang sukar, ruwet, dan banyak memperdayakan. Hal ini membuktikan bahwa banyak siswa yang mengalami kesulitan dalam belajar matematika, karena kebanyakan dari mereka bukan memahami konsepnya melainkan hanya menghapalnya. Menurut Rohana (2011: 111) dalam memahami konsep 
matematika diperlukan kemampuan generalisasi serta abstraksi yang cukup tinggi. Sedangkan saat ini penguasaan peserta didik terhadap materi konsep - konsep matematika masih lemah bahkan dipahami dengan keliru. Adapun indikator yang termuat dalam pemahaman konsep menurut Patria (2007: 22) diantaranya mampu menerangka secara verbal mengenai apa yang telah dicapainya, mampu menyajikan situasi matematika kedalam berbagai cara serta mengetahui perbedaa, mampu mengklasifikasikan objek-objek berdasarkan dipenuhi atau tidaknya persyaratan yang membentuk konsep tersebut, mampu menerapkan hubungan antara konsep dan prosedur, mampu memberikan contoh dan contoh kontra dari konsep yang dipelajari, mampu menerapkan konsep secara algoritma, mampu mengembangkan konsep yang telah dipelajari.

Integral adalah salah satu materi matematika yang disajikan pada sekolah menengah atas (SMA) kelas XII. Dalam integral banyak sekali sub bab yang harus dipelajari dan dipahami guna kelancaran pada materi yang akan dipelajari selanjutnya. Materi integral ini secara umum diperlukan sebagai dasar untuk mempelajari materi matematika lebih lanjut. Dengan demikian untuk mengetahui kesulitan belajar siswa dalam mempelajari integral dapat ditinjau dari pengetahuan siswa tentang konsep dalam integral.

Berdasarkan hasil wawancara penulis dengan guru matematika yang mengajar di kelas XII IPA SMA Tridharma MKGR Makassar, bahwa penguasaan materi integral oleh siswa masih tergolong rendah, di mana masih banyak siswa yang kurang memahami konsep pada materi integral. Selain itu, hasil belajar matematika siswa di kelas XII IPA pada materi integral tergolong rendah yaitu dengan nilai rata-rata 50 dari nilai KKM matematika yang ditetapkan pada sekolah tersebut yaitu 70. Hal ini disebabkan karena siswa kurang mampu memahami pelajaran integral terkhususnya pemahaman konsep.

Dari paparan diatas terungkap bahwa siswa dalam mempelajari materi integral masih sangat minim terutama dalam memahami konsep integral. Sehingga penulis tertarik untuk melakukan penelitian terkait pemahaman konsep siswa dalam menyelesaikan soal-soal integral pada siswa kelas XII SMA Tridharma MKGR Makassar. Adapun tujuan penulis dalam melakukan penelitian ini adalah untuk: 
Mendeskripsikan Pemahaman Konsep dalam Menyelesaikan Soal-Soal Integral Siswa Kelas XII SMA Tridharma MKGR Makassar.

\section{B. Metode Penelitian}

Jenis penelitian yang digunakan dalam penelitian ini adalah penelitian kualitatif. Penelitian dilaksanakan di SMA Tridharma MKGR Makassar yang beralamat di jalan Maccini Raya No. 29 Kelurahan Maccini, Makassar. Subjek dalam penelitian ini adalah siswa kelas XII IPA SMA Tridharma MKGR Makassar sebanyak 15 siswa. Dalam penelitian ini, subjek yang digunakan dalam penelitian ini sebanyak 5 orang yang dipilih dari siswa yang unggul pada kelas tersebut. Analisis data dalam penelitian ini dilakukan pada saat pengumpulan data berlangsung, dan setelah selesai pengumpulan data. Langkah-langkah dalam menganalisis data menurut Miles dan Huberman (Sugiyono, 2016:337) yaitu (1) Klasifikasi, adalah proses pemgelompokan semua data baik yang berasal dari hasil tes pemahamn konsep dan hasil wawancara dengan subyek penelitian. (2) Reduksi yaitu merangkum, memilih hal-hal pokok, memfokuskan pada hal-hal yang penting, dicari tema dan polanya, serta membuang yang tidak perlu. (3) Penyajian data penelitian kualitatif biasanya dalam bentuk uraian singkat, bagan, hubungan antar kategori, bagan alir, dan lain-lain. (4) Penafsiran data kualitatif dilakukan dengan membandingkan teori yang telah dikutip dalam bab teoritis terhadap temuan lapangan. Hasil penafsiran data kualitatif dapat berupa menguatkan teori yang ada, mempertanyakan, menambahkan ataupun menemukan teori (proposisi konsep) yang baru. Dan (5) Kesimpulan, penarikan kesimpulan didasarkan pada sajian data dengan tujuan memperoleh kesimpulan tentang pemahaman konsep dalam menyelesaikan soal-soal integral tak tentu. Data yang diambil dalam penelitian ini adalah jawaban siswa terhadap instrumen tes pemahaman konsep dan pedoman wawancara. Kemudian data tersebut di analisis dan dikelompokan hasil kerja siswa yang menjadi subjek penelitian dalam tiga kategori yaitu pemahamn tingkat tinggi, sedang dan rendah.

\section{Hasil Dan Pembahasan}

Kegiatan pengambilan data tes pemahaman konsep dan wawancara dilakukan di SMA Tridharma MKGR Makassar pada kelas XII IPA pada hari Kamis, 19 
Agustus 2019 dan diikuti oleh 15 siswa. Adapun daftar siswa kelas XII IPA dan skor penilaian pemahamn konsep masing-masing siswa dalam penelitian ini disajikan dalam tabel berikut.

Tabel 1. Daftar Skor Hasil Kerja Siswa Kelas XII IPA SMA Tridharma MKGR (Sumber:skor hasil tes siswa)

\begin{tabular}{ccccccc}
\hline \multirow{2}{*}{ No. } & & Kode Subjek & \multicolumn{5}{c}{ Indikator Pemahaman Konsep } \\
\cline { 3 - 7 } & & MUK & MOK & MCK & MKR & MAK \\
\hline 1 & A1 & 10 & 0 & 10 & 8 & 0 \\
2 & A2 & 4 & 2 & 10 & 0 & 0 \\
3 & A3 & 10 & 3 & 5 & 3 & 0 \\
4 & A4 & 10 & 3 & 5 & 0 & 0 \\
5 & A5 & 10 & 10 & 10 & 10 & 4 \\
6 & A6 & 3 & 10 & 3 & 10 & 0 \\
7 & A7 & 2 & 2 & 0 & 2 & 0 \\
8 & A8 & 2 & 3 & 5 & 5 & 0 \\
9 & A9 & 3 & 10 & 10 & 10 & 0 \\
10 & A10 & 3 & 5 & 2 & 0 \\
11 & A11 & 3 & 2 & 5 & 5 & 0 \\
12 & A12 & 0 & 2 & 5 & 2 & 0 \\
13 & A13 & 2 & 2 & 2 & 2 & 0 \\
14 & A14 & 3 & 10 & 10 & 10 & 5 \\
15 & A15 & 10 & 5
\end{tabular}

Hasil kerja siswa pada tabel 3 yang dipaparkan di atas, kemudian dikelompokan siswa yang paling banyak menjawab soal dengan benar sesuai indikator pemahaman konsep yaitu: indikator menyatakan ulang konsep hanya 5 orang dari 15 siswa yang menjawab soal dengan benar yaitu subjek dengan kode A1, A4, A5, A6, A15. Satu, Indikator mengklasifikasikan objek sesuai konsep hanya 4 orang dari 15 siswa yang menjawab soal dengan benar yaitu subjek dengan kode A5, A6, A10, A15. Dua, Indikator memberikan contoh dan bukan contoh sesuai konsep hanya 6 orang dari 15 siswa yang menjawab soal dengan benar yaitu subjek dengan kode A1, A2, A3, A5, A15. Tiga, indikator menyajikan konsep dalam bentuk representasi hanya 4 orang dari 15 orang siswa yang berhasil menjawab dengan benar yaitu subjek dengan kode A5, A6, A10, A15. Empat, indikator mengklasifikasikan konsep atau alogritma pemecahan masalah tidak ada 
satupun siswa yang dapat menjawab dengan benar. Hanya subjek A5, A15 yang dapat menjawab namun tidak sempurna dan subjek lainnya hanya menulis soal.

Dari keterangan tersebut di atas, peneliti memilih 5 orang subjek yang lebih banyak menjawab soal dari masing-masing indikator pemahaman konsep. Adapun siswa yang menjadi subjek penelitian terpilih disajikan dalam tabel berikut ini.

Tabel 2. Subjek Penelitian Terpilih

\begin{tabular}{lll}
\hline No & Indikator pemahaman konsep & $\begin{array}{l}\text { Kode } \\
\text { subjek }\end{array}$ \\
\hline 1 & Menyatakan ulang konsep (MUK) & A10 \\
2 & Mengklasifikasi objek sesuai konsep (MOK) & A1 \\
3 & Memberikan contoh dan bukan contoh sesuai konsep (MCK) & A6 \\
4 & Menyajikan konsep dalam bentuk representasi (MKR) & A5 \\
5 & Mengklasifikasikan konsep atau alogritma pemecahan masalah (MAK) & A15 \\
\hline
\end{tabular}

(Sumber:subjek terpilih)

Hasil kerja siswa yang menjadi subjek dalam penelitian ini sebagaimana yang tertera pada tabel 4 diatas, dikelompokan dalam tiga kategori tingkat pemahaman tinggi (A5 dan A15), tingkat pemahaman sedang (A6 dan A10), dan tingkat pemahaman rendah (A1). Dalam hal untuk memudahkan dalam kegiatan menganalisis data, maka setiap petikan jawaban dan wawancara diberi kode tertentu. Untuk petikan pewawancara diberi kode Z, sedangkan petikan wawancara subjek diberi kode 3 huruf singakatan yang merupakan indikator pemahamn konsep. Selanjutnya masing-masing dialog 1 digit setelahnya merupakan kode nomor soal yang dibahas, Sebagai contoh untuk pewawancara "Z1-01" berarti kode petikan pertanyaan pertama dari pewawancara untuk soal tes pertama. Begitupun dengan subjek, contoh "SMAK1-05" berarti kode petikan pertanyaan dari subjek dengan indikator mengklasifikasikan konsep atau alogritma pemecahan masalah untuk soal tes pertama pada jawaban yang kelima.

Paparan data pada bagian selanjutnya bertujuan untuk mendeskripsikan pemahaman konsep subjek pada indikator mengklasifikasikan konsep atau alogritma pemecahan masalah pada pertanyaan,

"Jika diketahui $\int f^{\prime}(x) d x=f(x)+c$, cocokanlah hasil dari pengintegralan dibawah ini, apakah hasil penguntegralannya benar atau salah?"

a. $\int x \sqrt{x^{2}-4} d x=\frac{1}{3}\left(x^{2}-4\right) \sqrt{x^{2}-4}+C$ 
b. $\int\left(3 x^{4}+19 x^{-3}\right) d x=\frac{3}{5} x^{5}+\frac{19}{-4} x^{-4}+c$

Berikut hasil tes dan wawancara oleh subjek:

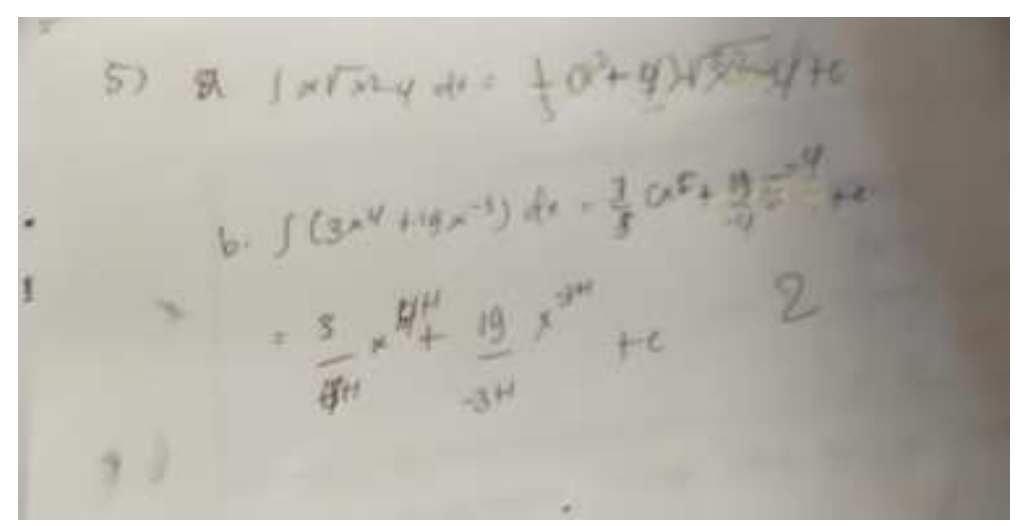

Gambar 1. Hasil tes SA5 MAK_05

$S a t u$, berdasarkan hasil pekerjaan yang ada pada gambar, jelas bahwa subjek bisa mengerjakan soal bagian 5.(b) walaupun tidak selesai dikarenakan siswa kurang memahami konsep. Artinya, subjek mengalami kendala dalam mengklasifikasikan konsep atau alogritma pemecahan masalah dengan pertanyaan yang sukar. Berikut ini disajikan petikan wawancara terhadap subjek kode A5 MAK_05 pada soal nomor 5. Dalam wawancara ini dipaparkan secara singkat mengenai kendala yang dialami siswa dalam menyelesaikan soal tersebut.

Tabel 3. Petikan wawancara SA5 MAK_05

\begin{tabular}{|c|c|}
\hline Kode & Penjelasan \\
\hline Z5-01 & Apa kamu paham dengan soal yang saya berikan? \\
\hline SMAK5-01 & Paham kak prtanyaannya (sambil senyum) \\
\hline Z5-02 & Kalau memang paham,apa perintah dari soal tersebut? \\
\hline SMAK5-02 & Cocokan jawaban pada yang tersedia pada soal ini \\
\hline Z5-03 & Lalu bagian mana kendala kamu dek, sehinnga hanya menjawab sebagian pertanyaan saja? \\
\hline SMAK5-03 & $\begin{array}{l}\text { Agak sukar soalnya kak,apalagi kalau pakai akar.(sambil menunjuk soal nomor 5). } \\
\text { Makanya saya hanya kerjakan yang bagian } 5 \text { b itupun tidak selesai karena agak sukar buat } \\
\text { saya kak. }\end{array}$ \\
\hline Z5-04 & $\begin{array}{l}\text { Apakah kamu tidak pernah pelajari sebelumnya contoh integral serupa ini (sambil } \\
\text { menunjukan soal nomor 5)? }\end{array}$ \\
\hline SMAK5-04 & (sambil senyum-senyum) saya lupa kak \\
\hline Z5-05 & Oke \\
\hline
\end{tabular}

Berdasarkan hasil petikan wawancara di atas, dapat dilihat bahwa subjek paham dengan perintah pada soal (SMAK5_02) namun subjek mengalami kendala 
dalam mengklasifikasikan konsep atau alogritma pemecahan masalah soal tersebut dengan konsep yang sudah dia peroleh dan memberikan alasan soalnya sukar bahkan subjek mengatakan bahwa soal integralyang menggunakan bentuk akar sulit. Sehinnga terlihat dengan jelas siswa hanya kerjakan beberapa langkah saja (SMAK5_03).

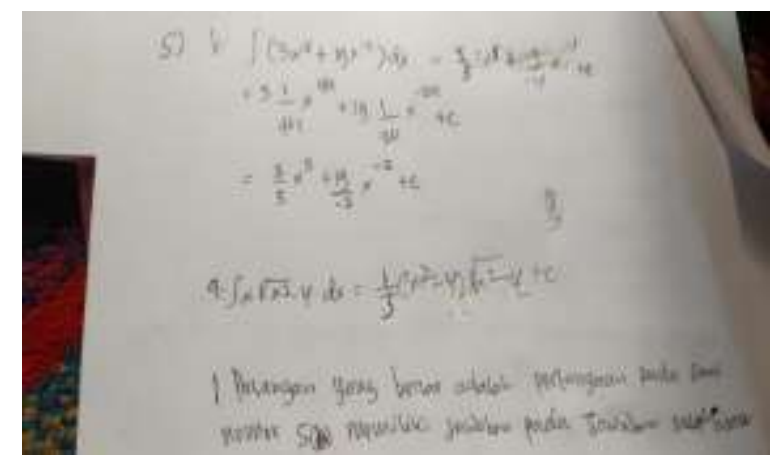

Gambar 2. Hasil Tes SA15 MAK_05

Dua, Berdasarkan hasil pekerjaan pada gambar, dapat dilihat dengan jelas bahwa subjek bisa mengerjakan soal bagian 5.(b) dan bisa mencocokan bahwa jawaban pada 5b itu salah. Dan pada pertanyaan 5a subjek tidak kerja sama sekali Artinya, subjek mengalami kendala dalam mengklasifikasikan konsep atau alogritma pemecahan masalah dengan pertanyaan yang sukar. Berikut ini disajikan petikan wawancara terhadap subjek kode A5 MAK_05 pada soal nomor 5. Dalam wawancara ini dipaparkan secara singkat mengenai kendala yang dialami siswa dalam menyelesaikan soal tersebut.

Tabel 4. Petikan wawancara SA5 MAK_05

\begin{tabular}{ll}
\hline Kode & Penjelasan \\
\hline Z15-01 & Apakah kamu paham dengan soal yang saya berikan? \\
SMAK15-01 & Paham kak \\
Z5-02 & Kalau memang paham,apa perintah dari soal tersebut? \\
\hline Kode & Penjelasan \\
\hline SMAK15-02 & Cocokan jawaban pada yang tersedia pada soal ini \\
Z5-03 & Lalu bagian mana kendala kamu dek, sehinnga hanya menjawab sebagian pertanyaan \\
& saja? \\
SMAK15-03 & Agak sukar soalnya kak, apalagi kalau pakai integral bentuk akar. yang tidak pakai akar \\
& saja kadang tidak bisa saya kerjakan apalagi yang seperti ini (sambil menunjuk soal \\
& nomor 5). Makanya saya hanya kerjakan yang bagian 5b dan saya dapat jawannya. dan \\
& untuk 5a saya tidak kerja karena saya tidak tau
\end{tabular}



Oke

Berdasarkan hasil petikan wawancara di atas, dapat dilihat bahwa subjek paham dengan perintah pada soal (SMAK5_02) namun subjek mengalami kendala dalam mengklasifikasikan konsep atau alogritma pemecahan masalah soal tersebut dengan konsep yang sudah dia peroleh dan memberikan alasan soalnya sukar bahkan subjek mengatakan bahwa soal integral yang menggunakan bentuk akar sulit. Walaupun pada kenyataannya subjek berhasil menjawab pertanyaan $5 b$ walaupun jawabanya belum lengkap dan subjek juga tidak bisa menyelesaikan soal yang dalm bentuk akar pada bagian 5a (SMAK5_03).

Analisis data selanjutnya pada bagian ini bertujuan untuk mendeskripsikan pemahaman konsep subjek pada indikator memberikan contoh dan bukan contoh sesuai konsep pada pertanyaan:

"Sebutkan masing-masing salah satu contoh dan bukan contoh dari integral (J) tak tentu yang kamu ketahui?"

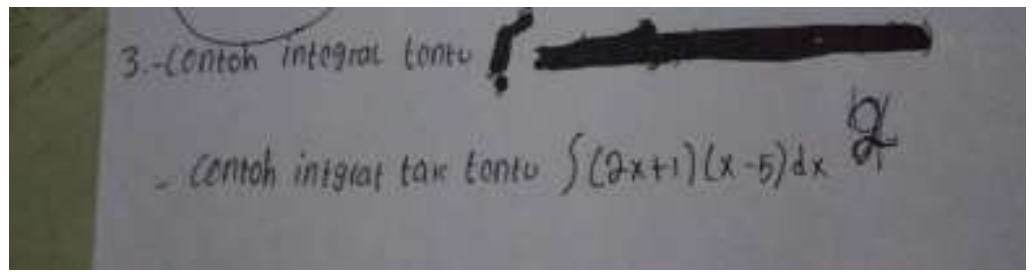

Gambar 3. Hasil Tes SA6 MCK_03

Tiga, Berdasarkan pada pekerjaan subjek diatas terlihat bahwa subjek dengan kode A6 dapat memahami konsep yang telah dipelajari, namun ada kendala dalam menjawab soal yang bukan merupakan contoh dari konsep. Berikut ini disajikan wawancara terhadap subjek SA6 MOK_03 pada soal nomor 3. Dalam wawancara ini dipaparkan secara singkat mengeni kendala yang dialami siswa dalam menyelesaikan soal tersebut.

Tabel 5. Petikan wawancara SA6 MCK_03

\begin{tabular}{ll}
\hline Kode & Penjelasan \\
\hline Z3-01 & Apakah Kamu paham pada soal ini (sambil menunjukan soal nomor tiga)? \\
SMCK3-01 & Paham kalau contohnya integral tak tentu
\end{tabular}




\begin{tabular}{|c|c|}
\hline Z3-02 & Coba jelaskan apa maksuds dari soal ini? \\
\hline SMCK3-02 & Sebutkan masing-masing satu contoh dari integral tentu dan integral tak tentu \\
\hline Z3-03 & Sebelumnya kamu pernah belajar integral tentu? Coba perhatikan kembali \\
\hline & catatan kamu yang sudah diberikan guru matematika! \\
\hline \multirow[t]{2}{*}{ SMC3-03 } & (sambil mengecek kembali bukunya) iya kak., saya hanya lupa kak dan tidak \\
\hline & baca materi mengenai integral tentu semalam \\
\hline Kode & Penjelasan \\
\hline Z3-04 & Sekarng kamu telah mengetahui contoh dari integral tentu? \\
\hline SMCK3-04 & iya kak \\
\hline Z3-05 & Tunjukan saya sebuah contoh integral tentu yang kamu ketahui? \\
\hline SMCK3_05 & (sambil buka buku paketnya) yang ini kak $\int_{-1}^{1} 2 x+1 d x$ \\
\hline \multirow[t]{2}{*}{ Z3_06 } & $\int_{-1}^{1} 2 x+1 d x$ coba jelaskan yang kamu ketahui apa itu yang -1 dan 1 pada \\
\hline & lambang integral? \\
\hline SMCK3_06 & Kalau -1 itu batas bawah dan 1 itu batas atas \\
\hline \multirow[t]{2}{*}{ Z3_07 } & Sekarng kamu telah mengeatahui contoh integral tentu, coba jelaskan yang \\
\hline & kamu ketahui tentang integral tentu dan integral tak tentu? \\
\hline SMCK_07 & Kalau integral tak tentu itu integral yang tidaka pakai batas dan integral tentu \\
\hline & itu integral yang pakai batas atas dan batas bawah. \\
\hline Z3_08 & Baik,terimakasih \\
\hline
\end{tabular}

Berdasarkan hasil wawancara di atas, dapat dilihat bahwa subjek sebenarnya paham mengenai contoh integral tak tentu walaupun hanya dapat menyebut contohnya saja tampa menyelesaikan dan siswa juga tidak bisa memberikan contoh integral tentu (SMCK3-01). Namun, setelah subjek kembali lagi membuka buku paket yang dimilikinya untuk melihat kembali materi integral yang telah dipelajarinya, barulah dia mengetahui contoh dari integral tentu dengan alasan lupa dan tidak membaca materi integral tentu semalam (SMC3-03). Selain itu, subjek juga bisa menunjukan sebuah contoh integral tentu pada buku paket yang dimilikinya (SMCK3_05). Dari wawancara diatas terlihat juga subjek sudah bisa dapat membedakan antara intigral tentu dan integral tak tentu,namun belum bisa mengerjakan (SMCK_07).

Analisis data selanjutnya pada bagian ini bertujuan untuk mendeskripsikan pemahaman konsep subjek pada indikator. Mengklasifikasikan konsep atau alogritma pemecahan masalah pada pertanyaan

“Jika diketahui $\int f^{\prime}(x) d x=f(x)+c$,cocokanlah hasil dari pengintegralan dibawah ini, apakah hasil penguntegralannya benar atau salah?" 
a. $\int x \sqrt{x^{2}-4} d x=\frac{1}{3}\left(x^{2}-4\right) \sqrt{x^{2}-4}+C$
b. $\int\left(3 x^{4}+19 x^{-3}\right) d x=\frac{3}{5} x^{5}+\frac{19}{-4} x^{-4}+c$

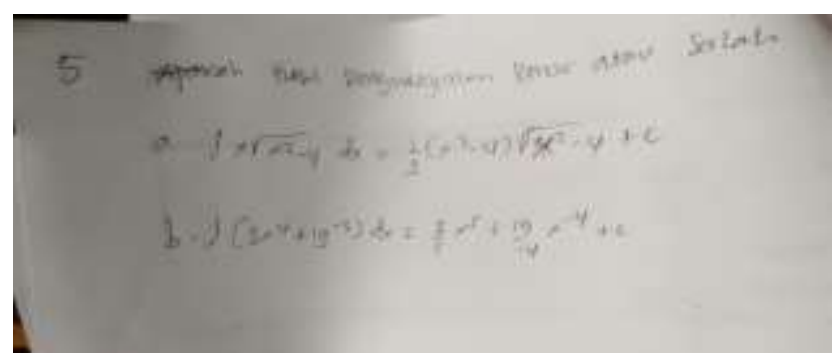

Gambar 4. Hasil Tes SA6 MAK_05

Empat,berdasarkan hasil pekerjaan di atas, dapat dilihat dengan jelas bahwa subjek mendapat kendala dalam mengerjakan soal pada pertanyaan kelima bahkan subjek tidak sama sekali menjawab walaupun selangkah, namun subjek hanya menulis kembali soal yang ada pada lembar pertanyaan. Artinya, subjek mengalami kendala dalam mengklasifikasikan konsep atau alogritma pemecahan masalah dengan pertanyaan yang sukar. Berikut ini disajikan petikan wawancara terhadap subjek kode A6 MAK_05 pada soal nomor 5. Dalam wawancara ini dipaparkan secara singkat mengenai kendala yang dialami siswa dalam menyelesaikan soal tersebut.

Tabel 6. Petikan wawancara SA6 MAK_05

\begin{tabular}{ll}
\hline Kode & Penjelasan \\
\hline Z5-01 & Apa kamu paham dengan soal yang saya berikan? \\
SMAK5-01 & Paham kak prtanyaannya (sambil senyum) \\
\hline Kode & Penjelasan \\
\hline Z5-02 & Kalau memang paham,apa perintah dari soal tersebut? \\
SMAK5-02 & Cocokan jawaban pada soal kak \\
Z5-03 & Lalu bagian mana kendala kamu dek, sehingga tidak menjawab sama sekali walaupun \\
& selangkah? \\
SMAK5-03 & soalnya sukar kak,apalagi kalau pakai akar.yang tidak pakai akar saja kadang tidak bisa \\
& saya kerjakan apalagi yang seperti ini \\
Z5-04 & Apakah kamu tidak pernah pelajari sebelumnya contoh integral serupa ini (sambil \\
& menunjukan soal nomor lima) dari guru matematika atau belajar melalui buku paket yang \\
& kamu miliki? \\
Z5-05 & (sambil senyum-senyum) saya lupa kak \\
\end{tabular}


Berdasarkan hasil petikan wawancara di atas, dapat dilihat bahwa subjek hanya paham dengan perintah pada soal (SMAK5_02) namun subjek mengalami kendala dalam mengklasifikasikan konsep atau alogritma pemecahan masalah soal tersebut dengan konsep yang sudah dia peroleh bahkan terlihat hanya menulis kembali soal dan memberikan alasan soalnya sukar bahkan subjek mengatakan bahwa soal integral yang menggunakan bentuk akar sulit (SMAK5_03).

Analisis data pada bagian selanjutnya, bertujuan untuk mendeskripsikan pemahaman konsep subjek pada indikator menyatakan ulang konsepi pada pertanyaan

“jelaskan pengertian dari integral tak tentu dengan menggunakan bahasa sendiri?"

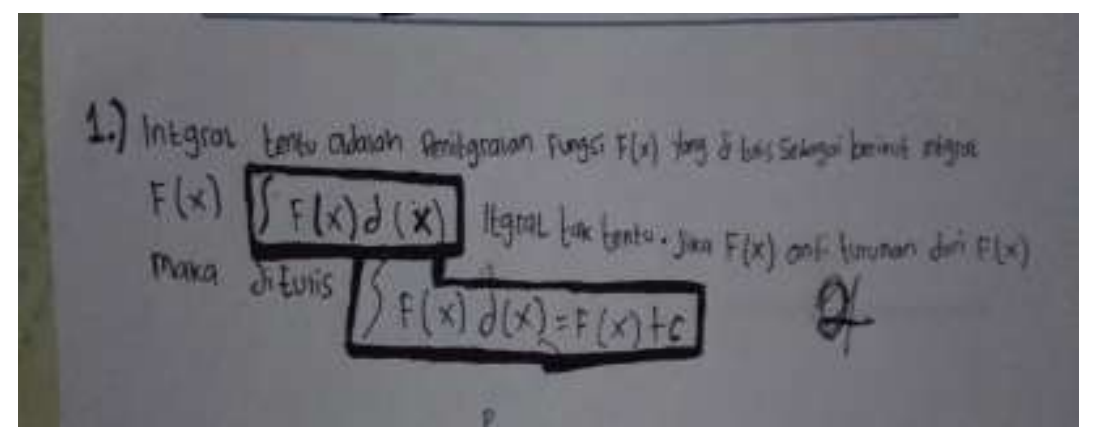

Gambar 5. Hasil Tes SA10 MUK_01

Lima, berdasarkan pada pekerjaan subjek diatas terlihat bahwa subjek dengan kode A10 kurang memahami konsep yang telah dipelajari dan diajarkan oleh guru, sehingga subjek mendapatkan kendala dalam menjawab soal dengan menggunakan bahasanya sendiri pada soal pengertian dari integral tak tentu. Berikut ini disajikan wawancara terhadap subjek A10 MUK_01 pada soal nomor 1. Dalam wawancara ini dipaparkan secara singkat mengeni kendala yang dialami siswa dalam menyelesaikan soal tersebut.

Tabel 7. Petikan wawancara SA10 MUK_01

\begin{tabular}{ll}
\hline Kode & Penjelasan \\
\hline Z1-01 & Apakah Kamu paham pada soal nomor 1? \\
SMUK1-01 & Paham kak,tapi tidak bisa saya ungkapkan dengan bahasa saya sendiri. \\
Z1-02 & Coba jelaskan apa yang kamu ketahui tentang integral tak tentu?
\end{tabular}




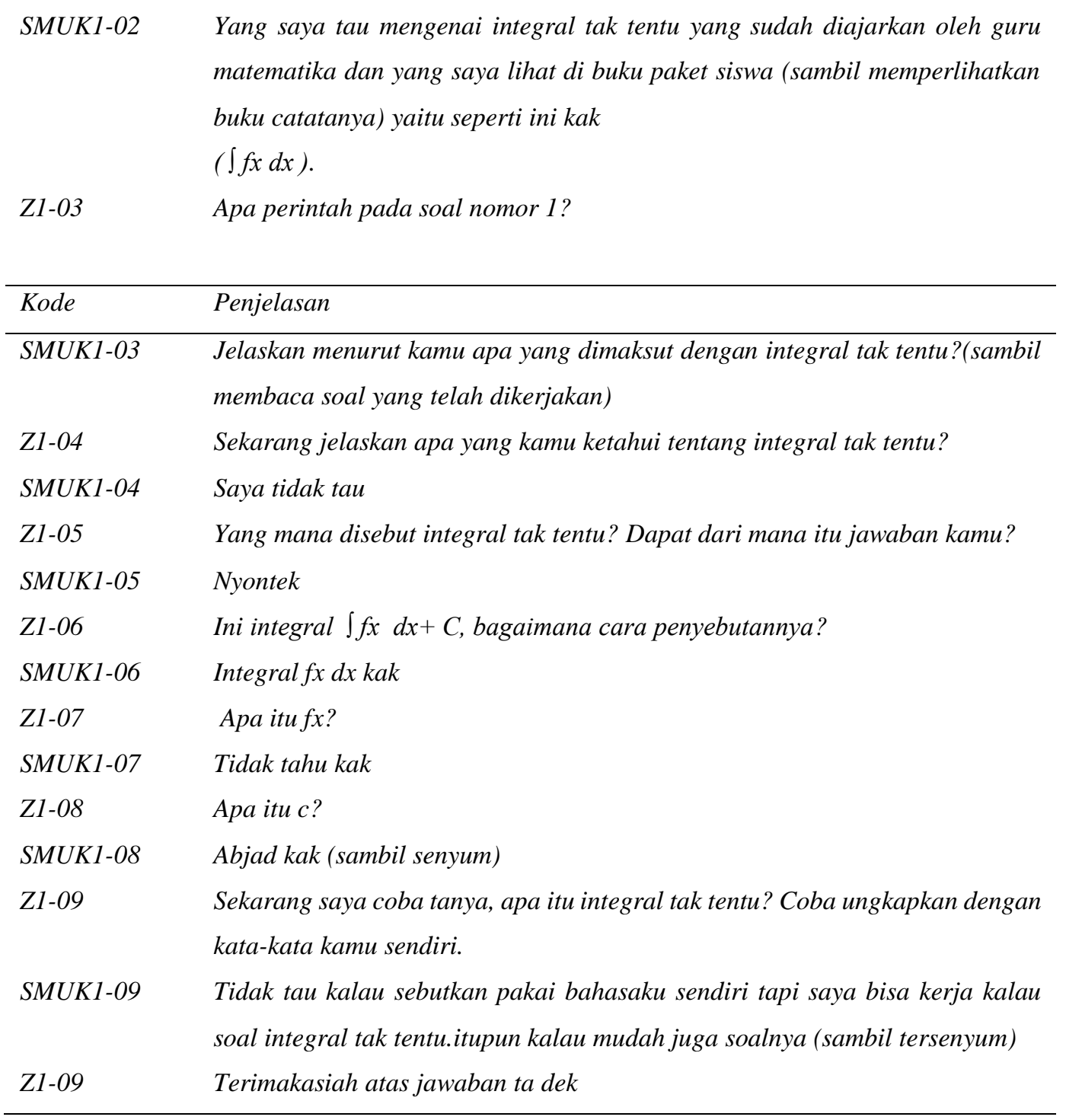

Berdasarkan hasil wawancara di atas, dapat dilihat bahwa subjek sebenarnya paham mengenai materi integral tak tentu . Akan tetapi, subjek mengalami kendala dalam menungkapkan pengertian integral dengan bahasanya sendiri (SMUK1-01). subjek hanya mengetahui apa yang ada pada buku paketnya (SMUK1-02) sehingga dampaknya subjek tidak bisa mengungakap maksut dari apa yang ada pada buku paketnya (SMUK1-03) dan tidak bisa pula dalam mengungkapkan konsep dengan bahasanya sendiri (SMUK1-04). Selain itu, subjek tidak bisa menyebutkan maksut dari integral $\int f x d x$. Subjek tidak tahu apa itu $f x$ yang mana itu merupakan fungsi yang diintegralkan (SMUK1-06) dan menyebut c adalah abjad yang semestinya adalah konstanta sembarang (SMUK1-07). Sehingga dampaknya subjek susah menyebutkan pengertian integral tak tentu dengan kata-katanya sendiri (SMUK108). 
Enam, dari data deskripsi tes dan wawancara kelima siswa yang menjadi subjek yang dipaparkan di atas, terlihat beberapa persamaan dalam menjawab soal sesuai dengan indikator pemahaman konsep. untuk lebih jelasnya dapat dilihat pada tabel dibawah ini.

Tabel 13. Persamaan Hasil Tes Subjek Setiap Indikator

\begin{tabular}{lcrrrrrc}
\hline No & Kode Subjek & \multicolumn{5}{c}{ Indikator Pemahaman Konsep } \\
\cline { 3 - 7 } & & MUK & MOK & MCK & MKR & MAK \\
\hline 1 & A1 & $\checkmark$ & - & $\checkmark$ & - & - \\
\hline 2 & A5 & $\checkmark$ & $\checkmark$ & $\checkmark$ & $\checkmark$ & - \\
\hline 3 & A6 & $\checkmark$ & $\checkmark$ & - & $\checkmark$ & - \\
\hline 4 & A10 & $\checkmark$ & $\checkmark$ & $\checkmark$ & $\checkmark$ & - \\
\hline 5 & A15 & $\checkmark$ & $\checkmark$ & $\checkmark$ & $\checkmark$ & - \\
\hline
\end{tabular}

(Sumber:hasil tes)

Dari paparan persamaan hasil tes subjek setiap indikator pada tabel di atas dapat diambil kesimpulan sebagai berikut: (1) Pada indikator pemahaman konsep menyatakan ulang konsep, terdapat kelima subjek dapat menjawab soal yang sama dengan benar. (2) Pada indikator pemahaman konsep mengklasifikasikan objek sesui konsep, terdapat hanya subjek A1 yang tidak dapat menjawab soal dengan benar sedangkan subjek A5, A6, A10, A15 dapat menjawab soal dengan benar. (3) Pada indikator pemahaman konsep memberikan contoh dan bukan contoh, terdapat subjek A6 yang tidak dapat menjawab soal dengan benar sedangkan subjek A1, A5, A10, A15 dapat menjawab soal dengan benar. (4) Pada indikator pemahaman konsep menyajikan konsep dalam bemtuk repesentasi terdapat hanya subjek A1 yang tidak dapat menjawab soal dengan benar sedangkan subjek A5, A6, A10, A15 dapat menjawab soal dengan benar. (5) Pada indikator pemahaman konsep mengklasifikasikan konsep atau alogritma pemecahan masalah, kelima subjek tidak dapat menjawab soal dengan benar namun subjek A5 dan A15 yang dapat menjawab namun belum sempurna. (6) Subjek A5 dan A15 memperoleh tingkat pemahaman tinggi karena paling banyak menjawab soal pada tiap indikator dan nilai hasil tes di atas KKM 70, Subjek A6 dan A10 memperoleh tingkat pemahaman sedang karena hanya menjawab sebagian soal pada tiap indikator dan nilai hasil tes di bawah KKM 70, Subjek A1 memperoleh tingkat pemahaman rendah karena 
paling banyak tidak menjawab soal pada tiap indikator dan nilai hasil tes di bawah 60.

\section{Kesimpulan}

Banyaknya siswa yang terpilih sebagai subjek penelitian ada 5 orang yang dianalisa tingkat pemahaman konsep dalam menyelesaikan soal-soal integral melalui indikator pemahaman yaitu, menyatakan ulang konsep (MUK), mengklasifikasi objek sesuai konsep (MOK), memberikan contoh dan bukan contoh sesuai konsep (MCK), menyajikan konsep dalam bentuk representasi (MKR), dan mengklasifikasikan konsep atau alogritma pemecahan masalah (MAK). Hasil analisis dari 5 subjek, kemudian dikelompokan dalam kategori tingkat pemahaman rendah, sedang dan tinggi.

Dari pengelompokan data hasil analisis kelima subjek, hanya 2 orang yang tergolong tinggi tingkat pemahamannya ditinjau dari paling banyak dapat menjawab soal pada tiap indikator dan nilai hasil tes dalam menyelesaikan soalsoal integral tak tentu di atas KKM (70) SMA tridharma MKGR Makassar. selebihnya 2 orang subjek tergolong pada tingkat pemahaman sedang dengan nilia tes di bawah KKM (70) atau nilai tes tidak kurang dari 60 dan hanya 1 orang dengan pemahaman tingkat rendah dengan nilai tes di bawah KKM (70) atau nilai tes kurang dari 60.

\section{Daftar Pustaka}

Maarif, Samsul. 2015. Integrasi Matematika Dan Islam Dalam Pembelajaran Matematika, (Online) Vol.4 No.2 (https://www.researchgate.net, diakses 6 Juli 2019).

Patria. 2007. Pemahaman Konsep. [online]. Tersedia di http//manfiturja. Blogspot.com/2011/11/pemahaman-konsep.html.diakses tanggal 18 Juli 2019.

Rohana. 2011. Pengaruh Pembelajaran Berbasis Masalah Terhadap Pemahaman Konsep Mahasiswa FKIP Universitas PGRI. Palembang :Prosiding PGRI

Ruseffendi, E.T. 2006. Pengantar kepada Membantu Guru Mengembangkan Kompetensinya dalam Pengajaran Matematika untuk Meningkatkan CBSA. Bandung: Tarsito.

Setiari, Sigit.,dkk. 2012. Penerapan Pendekatan Matematika Realistic (PMR) Dalam Peningkatan Kemampuan Menyelesaikan Soal Cerita Pecahan Pada 
Siswa Kelas V SD, (Online) Vol.1 No.2 (http://jurnal.fkip.uns.ac.id, diakses 6 Juli 2019).

Sugiyono. 2016. Metode Penelitian Pendidikan Pendekatan Kuantitatif, Kualitatif, dan R\&D. Bandung: Alfabeta.

Syarif, Mohamad. 2016. Pembelajaran Dengan Pendekatan Problem Solving Untuk Meningkatkan Kemampuan Berpikir Kritis Dan Kreatif Matematika Siswa SMA, (Online), (https://docplayer.info, diakses 22 Oktober 2018). 